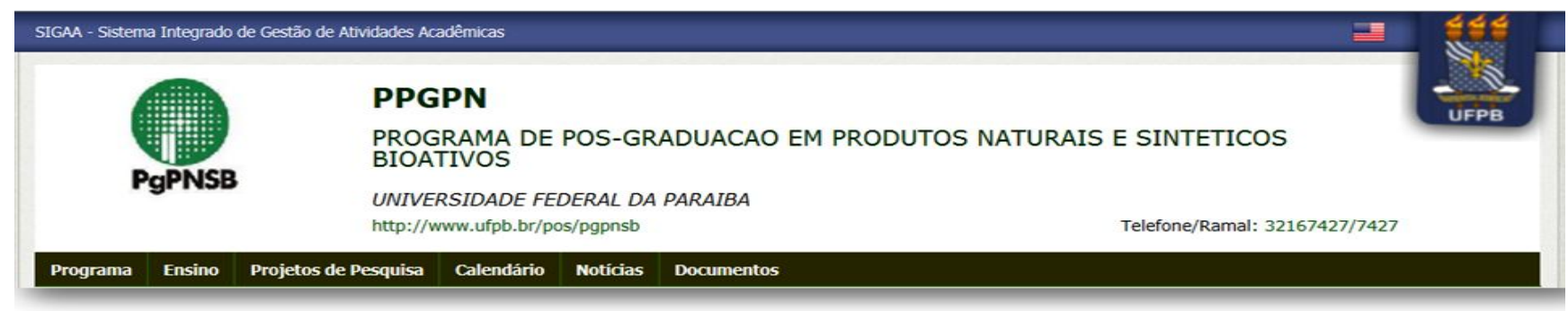

\title{
SciForum
}

MOL2NET

\section{CARQUEJA: CHEMICAL COMPOSITION AND FRAMACOLOGICAL EFFECTS}

\author{
Laiane Gonçalves ${ }^{1}$, Brenda Tavares ${ }^{2}$, Fernanda Galdino ${ }^{3}$, José Andrade ${ }^{4}$, Letícia Abrantes ${ }^{5}$, \\ Maria Sousa $^{6}$, Paula Lira ${ }^{7}$ and Lázaro Pereira ${ }^{8}$
}

1 Discente do curso de bacharelado em farmácia, Faculdade Santa Maria - FSM; ${ }^{2}$ Discente do curso de bacharelado em farmácia, Faculdade Santa Maria - FSM; E-Mails: brenda.tavares2016@outlook.com/laianevida_@hotmail.com. ${ }^{3}$ Discente do curso de bacharelado em farmácia, Faculdade Santa Maria - FSM; Email: galdinofernanda02@ gmail.com. ${ }^{4}$ Discente do curso de bacharelado em farmácia, Faculdade Santa Maria - FSM; Email: isaac-una@ hotmail.com.

${ }^{5}$ Discente do curso de bacharelado em farmácia, Faculdade Santa Maria - FSM; Email: letrabrantes@gmail.com. ${ }^{6}$ Discente do curso de bacharelado em farmácia, Faculdade Santa Maria FSM; Email: mr_bsf@hotmail.com. ${ }^{7}$ Discente do curso de bacharelado em farmácia, Faculdade Santa Maria - FSM; Email: paulagabriellasjp@ hotmail.com. $^{8}$ Docente do curso de bacharelado em farmácia, Faculdade Santa Maria - FSM; Email: lazarorobson@gmail.com.

* Author to whom correspondence should be addressed; E-Mail: laianevida_@hotmail.com;

Tel.: +55-83-99882-5387

Received: / Accepted: / Published:

Abstract: People all around the world are using plants directly or indirectly to treat symptoms or illnesses. It is beneficial, if used in a conscious and controlled way. Among the plants of therapeutic potential, Baccharis trimera, popularly known as carqueja and belonging to the family Asteraceae, stands out for having several proven pharmacotherapeutic properties, specially in the treatment of liver problems and problems related to digestion. The present work has the objective of describing the chemical properties, pharmacological and toxicological effects of Baccharis trimera. For the accomplishment of the bibliographic research the databases Scielo, Lilacs and VHL.The most abundant secondary metabolites of the genus Baccharis are flavonoids and terpenes, which confer several pharmacological attributes to the plant, specially antioxidant, antiviral, anti-inflammatory, antimicrobial and antiparasitic. However, there are also contraindications of the vegetable. Due to the abortive effect, the plant should not be consumed during gestation or lactation periods and, because of 
the hypotensive property, its consumption by hypotensive people is not recommended. Like other vegetables, the carqueja has benefits and harms. Therefore, before consuming plants and derivatives, one must be aware of its chemical properties and pharmacological effects, being necessary the orientation by a qualified professional to ensure a responsible and beneficial use.

Keywords: Baccharis; Asteraceae; Pharmacology.

\section{Introduction}

Since ancient times plants are used for medicinal purposes with the intention of relieving or curing symptoms or ailments. Among the plants with relevant therapeutic potential, we highlight Baccharis trimera, a representative of the Asteraceae family with proven pharmacotherapeutic properties, highlighting the diuretic and hepatoprotective properties (CAPRA et al., 2014).

The Asteraceae family is composed of more than 1,100 genera, distributed in several parts of the world, being found mainly in South America.., the genus Baccharis shows great

\section{Results and Discussion}

The pharmacological activities of Baccharis trimera are directly related to its chemical composition. The most abundant secondary metabolites of the genus Baccharis are the flavonoids and terpenes, which confer several pharmacological attributes to the plant, emphasizing antioxidant, anti-inflammatory, antimicrobial and antiparasitic activities (CAPRA et al., 2014).

Flavonoids, secondary metabolites widely found in carqueja, are polyphenols and stand out

\section{Materials and Methods}

This review was carried out in the literature, using articles of a scientific nature. The articles found were selected according to the research objective. After reading the articles, a summary of the articles was made.

for conferring antioxidant activity on vegetables. Among the flavonoids isolated from B. trimera, quercetin is of fundamental importance because, besides the antioxidant activity, it confers antimicrobial, antiviral and anti-inflammatory activities to the plant (CAPRA et al., 2014).

However, there are also contraindications of the vegetable. Due to the abortive effect, the plant should not be consumed during gestation or lactation and, because it has hypotensive properties, its consumption by hypotensive people is not recommended (RUIZ et al., 2008).

For the accomplishment of the bibliographic research the databases Scielo, Lilacs and VHL were used, having as descriptors: Baccharis, Asteraceae and Pharmacology. 


\section{Conclusions}

The bibliographic review made it possible to relate the pharmacological effect of carqueja to the presence of specific chemical constituents. Since the presence and quantity of secondary metabolites in its composition explain its pharmaceutical use.

Like other vegetables, Baccharis trimera has benefits and harms. Therefore, before consuming plants and derivatives, one must be aware of its pharmacological and toxicological properties, being necessary the proper orientation by a qualified professional, to enable a responsible and beneficial use to health.

\section{Acknowledgments}

I thank God first of all for the wisdom and opportunity to contribute to the process of knowledge formation through this work. Thanks also to Professor Me. Lázaro Robson de Araújo Brito Pereira for his dedication and guidance, and to the other collaborators.

\section{Author Contributions}

Carqueja is a plant with important medicinal properties, which makes it widely used for a wide range of purposes. Like all vegetable, it must be consumed properly and under the guidance of a qualified professional to reduce to the maximum the toxicological effects and, in this way contribute to the maintenance of health.

\section{Conflicts of Interest}

The author states that there was no conflict of interest.

\section{References}

HOCAYEN, Palloma de A.S. et al. Baccharis dracunculifolia methanol extract enhances glucosestimulated insulin secretion in pancreatic islets of monosodium glutamate induced-obesity model rats. Pharmaceutical biology, v. 54, n. 7, p. 1263-1271, 2016.

CAPRA, R. S. et al. Homeopathic preparations and culture environment in the production and yield of quercetin in carqueja [Baccharis trimera (Less) DC.]. Brazilian Journal of Medicinal Plants, v. 16, $\mathrm{n}$. 3, p. 566-573, 2014.

RUIZ, Ana Lúcia TG et al. Pharmacology and toxicology of Peumus boldus and Baccharis genistelloides. Brazilian Journal of Pharmacognosy, v. 18, n. 2, p. 295-300, 2008.

ALBERTO, M. R.; ZAMPINI, I. C.; ISLA, M. I. Inhibition of cyclooxygenase activity by standardized hydroalcoholic extracts of four Asteraceae species from the Argentine Puna. Brazilian Journal of Medical and Biological Research, v. 42, n. 9, p. 787-790, 2009. 